\title{
The Rights of Controlling State in Indonesia Against Land Tenure of Customary Law Community
}

DOI: https://doi.org/10.47175/rissj.v2i2.224

\author{
| Alpi Sahari | \\ Postgraduate Program, \\ Faculty of Law, Universitas \\ Muhammadiyah Sumatera \\ Utara, Indonesia \\ hassanelsan@gmail.com
}

\begin{abstract}
In order to achieve public welfare as tasks and responsibilities delegated to the government in the administration of public welfare (bestuurzorg) including the land sector which includes, among others, regulation, implementation of authority to enforcement of land law. Implementation of bestuurzorg by the government is more oriented towards economic democracy so that ignoring the principle of justice for indigenous peoples in controlling land parcels. The method used in this paper is juridical normative by applying an approach to legal principles and a legal synchronization approach both vertically and horizontally to the State's right to control over land tenure by customary law communities. The results show that land tenure for customary law communities in the UUPA emphasizes as long as it still exists and does not conflict with national interests. This implies that there has been legal pluralism. The occurrence of weak legal pluralism in national land law is indicated by the enactment of UUPA and its various implementing regulations as positive law in the form of written state/national law, on the one hand and on the other hand customary law which is generally unwritten and applies specifically to each other. The applicable customary law in each region. Weak legal pluralism is one of the factors causing legal disputes in substantive settings, especially in land disputes over customary rights which affect their implementation in the field and cause injustice. legal pluralism and making UUPA the center of various land regulations (legal centralism), and is the only land rule that applies nationally (legal unification). KEYWORDS

The rights of controlling state; customary law community
\end{abstract}

\section{INTRODUCTION}

Article 33 paragraph (3) of the 1945 Constitution has constitutionally provided the basis that the land and water and the natural resources contained therein are controlled by the State and used for the greatest benefit of the people. ${ }^{1}$ Further regulation of the 1945 Constitution regarding land is regulated in the Basic Agrarian Law Number 5 of 1960 especially Article 2 paragraph (1) which states that "Earth, water and space as well as natural resources contained therein are at the highest level controlled by the State as the power organization of all the people". This implies that the State has the authority as the governing body over the earth, water and space and the natural resources contained therein are the authority to regulate in order to achieve the greatest possible prosperity for the Indonesian people. This means that the state is obliged to realize general welfare in the

\footnotetext{
${ }^{1}$ Bachtiar Effendie, Kumpulan Tulisan Tentang Hukum Tanah, Alumni, Bandung, 1993, p. 2
} 
management of natural resources by taking an active role in implementing the interests of the community in various fields of life.

The conception of welfare that was put forward in the preamble to the 1945 Constitution furthermore is a national development target that leads to the formulation of the National Long-Term Development Plan (RPJPN) 2005-2025 as stipulated in Law Number 17 of 2007. In the 2005-2025 RPJPN determines that one of the direction, stages and priority scale of long-term development in 2005-2025 are the creation of a competitive nation to achieve a more prosperous and prosperous society by building a strong economic structure based on competitive advantages in various regions of Indonesia. The agricultural sector in a broad sense, including in the fields of plantation and mining, is an economic activity that is managed efficiently so as to produce quality commodities, a manufacturing industry that is globally competitive, the driving force for the economy, and services whose role is increasing with higher quality and competitive service quality. ${ }^{2}$

The RPJPN 2005-2025 is intended to provide direction as well as become a reference for the components of the nation (government, society and the business world) in realizing national ideals and goals. In addition, that the State of Indonesia as a modern law state has the duty to provide protection and is also obliged to participate in improving the welfare of society in all sectors. ${ }^{3}$

The government, in exercising its power to achieve the administration of public welfare, has the authority to manage natural resources for the greatest prosperity of the people, including among other things the state's right to control over land. The right to control by the state is an instrument that aims to use natural resources for the greatest prosperity of the Indonesian people. This implies that the state has the right to control the earth, water and natural resources contained therein, including space. Therefore, the implementation of state power indirectly constitutes an instrument of control over the mechanisms and procedures for the implementation of state rights and authorities based on law by providing the basis that every activity of organizing the life of the nation, including national development, must be based on law.

\section{RESEARCH METHODS}

This research is a normative legal research. Data sourced from library data (library research). This research tends to use secondary data in the form of primary and secondary legal materials. Primary legal materials, namely laws and regulations relating to the right to control by the State over land tenure by customary law communities.

\section{RESULTS AND DISCUSSION}

\section{The Principles of the Rights of Controlling State in Indonesia Against Land Tenure of Customary Law Community}

Article 2 paragraph (2) UUPA states that the right of control by the state includes the authority to regulate and administer the designation, use, supply and maintenance of earth, water and space. Then the state has the authority to regulate and determine the legal relationship between humans and water, earth and space. The state is also authorized to

\footnotetext{
${ }^{2}$ Law Number 17 of 2007 concerning the the National Long-Term Development Plan 2005-2025, Penerbit Fokus Media, Bandung, 2007, p. 84.

${ }^{3}$ Mochtar Kusumaatmadja, Penerapan Cita Hukum dan Asas-asas Hukum di Masa Kini dan Masa Yang Akan Datang, makalah pada Seminar Temu Kenal Cita Hukum dan Penerapan Asas-Asas Hukum Nasional, diselenggarakan oleh BPHN, Jakarta, May 1995, p. 2
} 
determine and regulate the relationship between people and legal actions relating to earth, water and space in its jurisdiction.

According to Article 2 paragraph (2), it is stated that the authority to control land by this state is used to achieve the greatest prosperity of the people in the sense of nationality, welfare and independence of the people and the sovereign, just and prosperous Indonesian constitutional state. The provisions of the articles contained in the UUPA require that the authority owned by the state must be adjusted to the rules of customary law which are still valid.

Tenure of land rights requires the state to respect the traditional customary rights (ulayat) of the community, as long as these traditional rights still exist. Respect for customary matters by depending on the requirement "as long as it still exists", which contains different interpretations from one another, thus creating a conflict about the status of the customary rights. This is of course based on the fact that customary rights do not have formal juridical evidence which often creates difficulties in adjusting the application of national agrarian laws. In principle, Article 2 of the UUPA contains the principle that all land rights are controlled by the state. Meanwhile, Article 18 UUPA contains the principle that ownership rights to land "can be revoked for the public interest".

Recognition of customary rights in the UUPA which emphasizes that as long as it exists and does not conflict with national interests, it means that there has been legal pluralism. This pluralism occurs in the form of weak legal pluralism, because in addition to the UUPA as a nationally applicable state law, certain community areas also apply the customary law system of indigenous peoples to customary lands. The occurrence of weak legal pluralism in national land law is indicated by the enactment of UUPA and its various implementing regulations as positive law in the form of written state/national law, on the one hand and on the other hand customary law which is generally unwritten and applies specifically to each other. the applicable customary law in each region. The dominance of national law, namely UUPA, is very strong against customary land law. The term pluralism of land law appears to point to the fact that there is a regulation regarding land law by customary law as well as by state law which is characterized by a centralistic regulatory nature. ${ }^{4}$

Weak legal pluralism is one of the factors causing legal disputes in substantive settings, especially in land disputes over customary rights which affect their implementation in the field and cause injustice, meaning that weak land law pluralism is often attempted to be eliminated because of political land policies adopted. more oriented to economic growth. The requirements put forward by the provisions of Article 3 and Article 5 of the UUPA are often the reasons for eliminating legal pluralism and making the UUPA the center of various land regulations (legal centralism), and the only land rule that applies nationally (legal unification). ${ }^{5}$

In addition, the interpretation of the contents of Article 2 and Article 18 of the UUPA is a source of disputes that arise because several articles in the contents of the law are declared unable to resolve the problems that arise. In general, the problems that arise are often grouped by experts into four groups, namely: First, which is directly or indirectly related to the social function of land rights. Second, regarding the arrangement of land tenure or restructuring of land ownership/control. Third, regarding land stewardship, including the obligation to maintain the land. Fourth, regarding land rights and regarding legal certainty of land rights. ${ }^{6}$

\footnotetext{
${ }^{4}$ Ida Nurlinda, Prinsip-prinsip Pembaruan Agraria, Rajawali Pres, Jakarta, 2009, p. 116

${ }^{5}$ Ibid, p. 119

${ }^{6}$ M. Yamin, Beberapa Dimensi Filosofis Hukum Agraria, Pustaka Bangsa Press, Medan, 2003, p. 4
} 
Article 3 of the UUPA states that insofar as this traditional customary law rights exist, it must be in such a way that it is in accordance with the national and state interests based on national unity and must not conflict with higher regulations. What is meant by ulayat rights and similar rights is what in adat literature is called beschikkingsrecht. Thus, the state recognizes (recognitie) the existence of customary rights to those who are entitled to receive it as customary holders. Customary rights holders must be asked for their opinion in the process of transferring control over this land by the state, however, rights holders may not obstruct the granting of rights if the granting of these rights is deemed necessary for broader interests. ${ }^{7}$

Recognition and protection for customary communities who hold customary rights as contained in Article 3 of the UUPA is subsequently introduced by the constitution, namely the 1945 Constitution (the fourth amendment), especially Article 18B paragraph (2) which states that "The State recognizes and respects indigenous peoples and traditional rights as long as they are still alive and in accordance with the development of society and the principles of the Unitary State of the Republic of Indonesia, which are regulated in law ". In its implementation, the constitutional mandate contained in this constitutional basis has not been carried out seriously by the government, especially regarding the recognition and protection of customary rights and traditional rights of indigenous peoples in a fair manner over the management of natural resources and agrarian reform.

The essence of Article 18B of the 1945 Constitution (fourth amendment) is that the implementation of the main tasks of the state for the welfare of society for the management of natural resources must pay attention to traditional wisdom that lives and develops in the midst of society. This means that the implementation of the basic rights of indigenous peoples needs to be emphasized, because their rights have so far been neglected. Customary law communities are indigenous peoples of a customary law fellowship, which from their birth and life are bound and subject to the customary laws that apply in that area. Customary law, according to Snouck Hurgronje, grows and develops from empirical social developments that are considered good by the community and have been legitimized by customary rulers so that it must be obeyed. ${ }^{8}$

Based on the legal provisions contained in statutory regulations, the status of customary rights on the one hand is still recognized as long as its existence can still be proven, but on the other hand, the customary rights must be subject to national interests which rank higher. Within this blurred limitation, there are often different interpretations of the extent to which these customary rights can be taken into account and respected in the process of delegating land tenure rights, especially those involving state interests or other interests legalized by the state. The state can explain its tenure rights based on formal juridical with existing regulations, however, this customary right does not have a clear legal measure, as long as it cannot be proven through written facts which are considered valid.

\section{Land Tenure Disputes by Customary Law Community}

Customary law communities are indigenous peoples of a customary law fellowship, which from their birth and life are bound and subject to the customary laws that apply in that area. Customary law, according to Snouck Hurgronje, grows and develops from empirical social developments that are considered good by the community and have been legitimized by customary rulers so that it must be obeyed. ${ }^{9}$ Indigenous peoples' rights to land are rights to

\footnotetext{
${ }^{7}$ Penjelasan Umum II No. 3 UUPA Nomor 5 Tahun 1960

${ }^{8}$ Wignjodipuro, Pengantar dan Asas-asas Hukum Adat, Gunung Agung, Cetakan Kedua, Jakarta, 1982, p. 44

${ }^{9}$ Wignjodipuro, Pengantar dan Asas-asas Hukum Adat, Gunung Agung, Cetakan Kedua, Jakarta, 1982, p. 44
} 
use and utilize land. This implies that the rights of indigenous peoples are communal rights of customary communities, not personal or individual rights for customary law communities, although it is found that the existence of individual control from indigenous peoples does not mean that it is an individual right but an association right that gives to individual communities custom for its control.

The subjects of customary law community rights to land are customary law communities, whether they are legal alliances based on the same place of residence (territorial) or those based on descent (genealogical), who are known by various unique names in several regions, for example ethnicity, clan, dati, hamlet, nagari and so on. If there is a person who seems to be the subject of customary rights, then that person is the customary leader or elder who gets the delegation of authority from the customary law community concerned according to the provisions of their customary law. Customary leaders are not the subject of ulayat rights, but officers of the customary law community in exercising the authority concerned with ulayat rights.

Recognition of the customary rights of indigenous peoples is contained in the Basic Agrarian Law as the basic framework for national land law, among others, Article 3 of the UUPA states that as long as the reality is that traditional customary law rights are still recognized but must be in accordance with national and state interests based on unity nation and must not conflict with higher regulations. This article affirms that it is recognized, meaning that there is recognition from the State (in the context of the State's right to control) of the existence of customary rights and that it is not allowed to conflict with higher regulations which do not constitute unilateral claims by the community that the land in question is controlled by the community as customary rights. In addition, tenure does not mean ownership rights (indigenous peoples do not recognize the term property rights for individuals as regulated in western law/Civil Code). Based on the UUPA as a provision of national land law, its formation is based on customary law that regarding the granting of rights as legal subjects must be followed by formal legality.

The Basic Agrarian Law of 1960 converts "Western Rights" and "Customary Rights" into new rights, for example, "Western rights" such as eigendom ${ }^{10}$, agrarische eigendom $^{11}$ and grant sultan $^{12}$ and customary rights such as yasan ${ }^{13}$, gogolan ${ }^{14}$, sanggan $^{15}$ and pekulen $^{16}$ (permanent rights) all become property rights under the new law. "Western rights" such as vruchtgebruik ${ }^{17}$ and gebruik $^{18}$ and customary rights such bengkok ${ }^{19}$, lungguh ${ }^{20}$ anggaduh, ${ }^{21}$, all become usage rights. Erfpacht rights (lease rights for up to 75 years) and concession rights become Business Use Rights.

\footnotetext{
${ }^{10}$ Property Rights, Civil Code. Article 570

${ }^{11}$ Indigenous Indonesian land ownership rights. The Indische Staatsregeling, Article 51 (7).

${ }^{12}$ Land ownership rights held by the Sultan

${ }^{13}$ Rights based on customary law. In some areas land based on this right cannot be sold to people outside the village.

${ }^{14}$ Synonym for common land given to villagers with the right to use it

${ }^{15}$ Collective land given to the original villagers with only the right to cultivate it.

${ }^{16}$ Synonym for collective land given to villagers with the right to cultivate or use.

${ }^{17}$ The right to use the produce of land as described in Article 756 of the Civil Code.

${ }^{18}$ Use rights based on the Civil Code

${ }^{19}$ Land cultivated by village officials as a substitute for wages

${ }^{20}$ Nama lain untuk tanah bersama yang diberikan kepada pejabat desa sebagai pengganti gaji.

${ }^{21}$ Tanah yang dimiliki oleh kerajaan yang diberikan kepada orang-orang dengan hak garap
} 
Ulayat rights are the control of indigenous peoples over land or are termed in the customary literature called beschikkingsrecht. Apart from that, the state recognizes (recognitie) the existence of customary rights to those who are entitled to receive them as customary holders. Customary rights holders must be asked for their opinion in the process of transferring control over this land by the state, however, rights holders may not obstruct the granting of rights if the granting of these rights is deemed necessary for broader interests such as granting forest area status. It should be emphasized that in the case of beschikingsrecht, what is meant is the right to control or use the land. This is the opinion of Van Vollenhoven. ${ }^{22}$ So that the internal and external functions can be concluded as usage rights by every member of the community in the fellowship area and land for the common interest of the community in the fellowship area and other alliances. Land rights according to customary law not only give authority, but also place obligations on those who own or control the land. Therefore, those who have individual rights must work in the sense that they do not abandon the land. When neglected, the individual rights will be nullified and the land will return to become communal land. Likewise, if the individual rights are exercised continuously or from generation to generation, the ulayat rights will weaken so that in the end the customary rights will no longer be visible. According to Van Vollenhoven, the highest rights of customary rights can be owned by een stam (tribe), een dorpenbond and eendorp (village).

The existence of the customary rights of the customary community which caused disputes also occurred in North Sumatra, especially in the city of Medan, which is mostly located in the city of Medan, including the Tanjung Morawa area which is part of the Deli Sultanate. The emergence of the dispute began with the transfer of rights to land originating from the basis of rights in the form of the Grand Sultan, the transition to the Grand Sultan involving many parties including Notary and PPAT who are vulnerable to being involved in legal issues. One form of the Grand Sultan that caused many legal problems was the position of the grand abundance of the gifts of the Deli Sultanate which was transferred without obtaining the approval of the Deli Sultanate. Grand abundant kurnia is the surrender of a plot of land by the sultan to be used, as a place to live for the kaula. If it is no longer used and re-allocated, the land that has been handed over is handed back to the sultan. Land surrendered by the sultan may not be transferred without obtaining permission from the Sultan. ${ }^{23}$ Grant Sultan is a certificate regarding land rights that can be owned by indigenous people with the permission, granting or recognition of the Sultan of the rights to the land given to his vassal. In 1889 the Dutch governorate had established an example deed which became known as the Grant. Then in 1890 a certificate was issued by the Sultan regarding the granting of a plot of land known as kurnia, which means that the sultan gave up a plot of land to his vows as a gift to his vows. This Grand is handwritten using Arabic letters. In these documents, a provision was added, stating that the right granted will be invalidated if the land is not used properly and that the transfer of rights to someone else must be with the Sultan's permission. ${ }^{24}$

The Sultanate of Deli is an area that has a separate government including separate provisions on land using the Swapraja Land Law. The land regulations in the Deli Sultanate use land regulations in East Sumatra, which is why the Deli Sultanate is one of

22 Sajuti Thalib, Hubungan Tanah Adat dengan Hukum Agraria di Minangkabau; Bina Aksara, Jakarta, 1985, hlm. 22-23

${ }^{23}$ Bachtiar Effendie, Loc.cit

${ }^{24}$ Berita Acara Penyidikan, Subdit Tanah dan Bangunan Direktorat Reserse Kriminal Polda Sumatera Utara, 2016 
the Swapraja areas. Lands in the Swapraja areas in East Sumatra are owned by rights created by the Swapraja government. In the area of the Deli Sultanate, for example, the land that is owned is known as: $:^{25}$

a. Grant Sultan, a kind of customary property right, is granted by the Swapraja Government.

b. Controleur grant, given by the Swapraja government for non-Swapraja subjects.

c. Grant Deli Maatschappij, located in the city of Medan and given by Deli Maatschappij, a company that has a large tobacco plantation.

Grant Sultan was imprisoned, as long as it related to his Malay part, was issued by the failed heads (XII kota, Serbanyaman, Sukapiring and Senembah Deli). After being signed by the head failed and given the stamp Grant was sent to the Sultan and Cap. In areas where there used to be Malay kingdoms such as Percut Sungai Tuan, Padang and Bedagai, a similar procedure was followed. In areas governed directly by the Sultan such as around Medan (Kota Matsum, P. Brayan, Titipapan, Glugur, Labuhan, Tanjung Morawa and the Medan area itself). The Grand Sultan was immediately signed by the Sultan Himself. The sultan's grants were given various forms, such as Soerat Penentoean Milik, which meant giving a piece of land to become his property. Geran Menento presses Haq Kebon, which is to give permission to have the right to one garden or Soerat Penjerahan Hak Pengoesahai Land, which is to give up the right to control a plot of land. ${ }^{26}$

Based on the description above, that the transfer of the grand sultan Abundant Kurnia involved many parties including notaries and PPATs so that they are prone to legal issues, it can be described in the case below: ${ }^{27}$

"Whereas based on Deed Number 04, dated December 11, 2015, regarding a power of attorney, which was carried out before a Notary ..., the Sultanate of Deli on behalf of ... ..., Giving power to..., the contents of the power of attorney include: First, to act either individually or collectively representing giving power anywhere and facing anyone to manage and protect and pay attention to the rights and interests of the power-giving in matters relating to land and assets which belonged to the legacy of the Deli Sultanate in general, in particular several plots of land covering 33 (thirty three) concessions between the Sultan of Deli and the Dutch Ondreneming. Second, to represent the first party to demand, hear, examine, approve, reject, ask for justification, pay attention to and give priority to all matters and interests of the authorizer. Third, to acquire, control, sell, surrender, release all rights of the grantor over all or part of the land and assets. Subsequently, on April 21, 2016 at around 13.00 West Indonesia Time, there was a handover of rights to one of the beneficiaries.... at Bank Danamon, Jalan Diponegoro, Medan, on the handover of land rights located on Jalan ...... belonging to the Sultanate of Deli (Grand Sultan Rahim Lumber Kurnia's letter Number: 106 dated January 1, 1907) between... .. with... .. amounting to Rp. 1,000,000,000, - (one billion rupiah) and the object of the transfer of rights over the land is still controlled by the heirs of..... That upon handing over the money to one of the recipients of the power of attorney on behalf of.... in the amount of Rp. 1,000,000,000, - (one billion rupiah) then the Sultanate issued a statement letter of handover of land rights located on Jalan.... signed by Pemangku Sultan Deli on behalf of.... with number: 016.04 / IM - PSD / 2016, dated 18 April 2016 and the letter is used by.... (right recipient) to be involved in the management of the issuance of land rights at BPN which is located... based on the sale and purchase agreement deed before a Notary and the Sale and Purchase Deed made by PPAT".

\footnotetext{
${ }^{25}$ Ibid

${ }^{26} \mathrm{Ibid}$

${ }^{27}$ Ibid
} 


\section{CONCLUSION}

Social welfare for land tenure by customary law community is an inseparable part of the philosophical foundation of the Republic of Indonesia and is the estuary of the national development agenda. In order to achieve social welfare for all Indonesian people, it means that the Republic of Indonesia does not adopt a welfare state as adopted by developed countries. The principle of social justice is explicitly embraced by the constitution, which is contained in Article 27 and Article 34 of the 1945 Constitution which mandates government responsibility in the development of social welfare, while Article 33 of the 1945 Constitution which deals with national economic issues is in Chapter XIV of the 1945 Constitution entitled "social welfare". This means that the development of the national economy must lead to improving social welfare.

Based on the conceptual basis of the welfare state, it outlines that the government in exercising its power has the authorities in managing natural resources with the aim of the social welfare of the Indonesian people. This implies that there is a right from the state to control resources consisting of earth, water and natural resources contained therein with the aim of being used for the greatest prosperity of the people. If the definition of control is related to the definition of rights, then the right to control is addressed to the state as a legal subject (having rights and obligations). Thus the right to control the state over the earth, water and natural resources contained therein, including space, is of a public nature because it contains a number of obligations and responsibilities that are public in nature. Therefore, regulations regarding land tenure by customary law communities in addition to the state's right to control the land, water and natural resources contained therein can be formulated in the basis of the Indonesian constitution as a fundamental norm.

\section{REFERENCES}

Bachtiar Effendie. (1993). Kumpulan Tulisan Tentang Hukum Tanah, Alumni, Bandung, 1993

General Explanation II No. 3 UUPA Number 5 of 1960

Law Number 17 of 2007 concerning the Long-Term National Development Plan for 20052025, Penerbit Fokus Media, Bandung, 2007

Mochtar Kusumaatmadja. (1995). Penerapan Cita Hukum dan Asas-asas Hukum di Masa Kini dan Masa Yang Akan Datang, makalah pada Seminar Temu Kenal Cita Hukum dan Penerapan Asas-Asas Hukum Nasional, diselenggarakan oleh BPHN, Jakarta.

Ida Nurlinda. (2009). Prinsip-prinsip Pembaruan Agraria, Rajawali Pres, Jakarta

M. Yamin. (2003). Beberapa Dimensi Filosofis Hukum Agraria, Pustaka Bangsa Press, Medan

Wignjodipuro. (1982). Pengantar dan Asas-asas Hukum Adat, Gunung Agung, Cetakan Kedua, Jakarta.

Wignjodipuro. (1982). Pengantar dan Asas-asas Hukum Adat, Gunung Agung, Cetakan Kedua, Jakarta.

Sajuti Thalib. (1985). Hubungan Tanah Adat dengan Hukum Agraria di Minangkabau; Bina Aksara, Jakarta. 